отделение Российской академии наук, Институт горного дела, Дальневосточный федеральный университет. Владивосток, 2009.

8. Старожилов В. Т. Геодинамическая эволюция зон перехода северо-востока Азии к Тихоокеанской плите / В. Т. Старожилов // Гидрометеорологические и географические исследования на Дальнем Востоке: материалы 5-й юбилейной научн. конф. «К всемирным дням воды и метеорологии». Владивосток, 2004. - С.85-88.

9. Старожилов В.Т. Ландшафтные геосистемы Сахалинского звена окраинно-континентального ландшафтного пояса Тихоокеанской России // Проблемы региональной экологии. - 2016. - № 5. C. 53-57.

10. Старожилов В.Т. Эколого-ландшафтный подход к промышленным территориям юга Дальнего Востока // В сборнике: Современные геофизические и географические исследования на Дальнем Востоке России. материалы 9-й научной конференции, Владивосток: конференция приурочена к Всемирным дням воды и метеорологии, а также к 110-летию ДВГУ и 45-летию ГФФ. Дальневосточный государственный университет, Институт окружающей среды; под редакцией Н. В. Шестакова. Владивосток, 2010. С. 155-158.

11. Старожилов В.Т. Проблемы ресурсопользования, структура и пространственная организация ландшафтов приокеанских Дальневосточных территорий // В сборнике: Науки о Земле и отечественное образование: история и современность. материалы Всероссийской научнопрактической конференции, посвященной памяти академика РАО А. В. Даринского. Российский государственный педагогический университет им. А. И. Герцена, факультет географии. 2007. С. 310-312.

12. Старожилов В. Т. Ландшафтные геосистемы Сахалинского звена Тихоокеанской России // В сборнике: Научная дискуссия: гуманитарные, естественные науки и технический прогресс. Материалы VII Всероссийской научно-практической конференции. 2015. С. 54-64.

\title{
Старожилов В.Т. \\ Районирование орогенных ландшафтных областей тихоокеанского ландшафтного пояса России
}

Тихоокеанский международный ландшафтный центр ШЕН ДВФУ, Дальневосточный Федеральный университет (Россия, Владивосток)

doi: 10.18411/lj-04-2021-74

\section{Аннотация}

Работа представляет собой продолжение комплексных исследований в целом сформировавшейся ландшафтной школы профессора В.Т. Старожилова (doi:10.24411/1728-323X-2020-13079, doi:10.18411/1j-05-2020-26). Рассматриваются районирование ландшафтных областей Тихоокеанского ландшафтного пояса России (doi: 10.18411/lj-01-2021-32), включающего Сихотэ-Алинскую, Нижнеамурскую, Камчатско-Курильскую, Сахалинскую и другие ландшафтные области и сопряженные с ними окраинные моря. Констатируется, что на основе применения ландшафтной методологии, на основе сопряженного анализа и синтеза межкомпонентных и межландшафтных связей с учетом окраинно-континентальной дихотомии и данных по орогеническому, орографическому, климатическому и фиторастительному факторам формирования географически единых территорий в рамках горного ландшафтоведения, проведено районирование ландшафтных областей и выделены горные и равнинные провинции. В Сихотэ-Алинской области - Самаргинская, Северо-Сихотэ-Алинская, Восточно-Сихотэ-Алинская, Центрально-Сихотэ-Алинская, Западно-Сихотэ-Алинская, Западно-Приморская равнина, Восточно-Маньчжурская, Южно-Приморская; в Сахалинской - Восточно-Сахалинская, Западно-Сахалинская, Центрально-Сахалинская и Северо-Сахалинская; в Камчатско - Курильской - Западно-Камчатская, СрединноКамчатская, Центрально-Камчатская, Восточно-Камчатская провинции. Обособляются внутри ландшафтных областей, включают ландшафты подклассов и родов, определяемые высотностью, типами растительности, рельефом и вещественными комплексами фундамента - четырьмя ведущими факторам: орогеническому, орографическому, климатическому и фиторастительному. Они является одной из 
базовых моделей «фундаментом» для построения гармонизированных с природой и связанных с океаном экологических, сельскохозяйственных и других отраслевых моделей освоения, в целом пространственного развития областей и их провинций. Отмечается, что при исследовании применялись компьютерные технологии векторнослоевого ландшафтного метода, которые в свою очередь создают платформу для разработки планов и проектов освоения. Они также является платформой для обучения студентов. Приводятся данные о картографической обеспеченности современными векторно-слоевыми цифровыми материалами.

Ключевые слова: районирование, провинции, области, освоение, ландшафт, пояс.

\section{Abstpact}

Work is a continuation of comprehensive studies in general formed by the Landscape School of Professor V.T. Old-timer (DOI: 10.24411 / 1728-323x-2020-13079, DOI: 10.18411 / LJ-05-2020-26). The zoning and structural organization of the landscape areas of the Pacific Landscaping Belt of Russia are considered (DOI: 10.18411 / LJ-01-2021-32), which includes Sikhote-Alin, Nizhnemur, Kamchatka-Kuril, Sakhalin and other landscape areas and conjugate seas. It is stated that, on the basis of the use of landscape methodology, based on the conjugate analysis and synthesis of intercompontent and intercompound and intercompoundal dichotomy and orogenic, orographic, climatic data and the formation of geographically unified territories in the framework of mountain landscape, the landscape regions and Mountain and flat provinces are highlighted. In the Sikhote-Alina region Samaginskaya, North-Sikhote-Alinsky, East-Sikhote-Alinsky, Central-Sikhote-Alinskaya, West Sikhote-Alinskaya, West Primorskaya Plain, East Manchu, South Primorskaya; in Sakhalin - East Sakhalin, West Sakhalin, Central Sakhalin and North-Sakhalin; In Kamchatsko - Kuril - West Kamchatka, Mid-Kamchatka, Central Kamchatka, East Kamchatka provinces. They are isolated within landscape areas, include landscapes of subclasses and genera, determined by altitude, types of vegetation, relief and material complexes of the basement - four leading factors: orogenic, orographic, climatic, and phytovegetation. They are one of the basic models "foundation" to build harmonized with nature and the ocean-related environmental, agricultural and other sectoral models of development, in general, the spatial development of areas and their provinces. It is noted that the study used computer technology of the vector-layered landscape method, which in turn create a platform for developing plans and development projects. They are also a platform for students learning. The data on the cartographic provision of modern vector-layer digital materials are given.

Keywords: zoning, provinces, regions, development, landscape, belt.

Введение. В последние десятилетие Президентом и правительством РФ большое внимание уделяется пространственному развитию Востока России, экологии и учету природных условий освоения и создания совокупного знания географического пространственного строения, в том числе для создания базовых основ размещения конкурентоспособных технологий и фирм. Настоящее исследование является продолжением изучения ландшафтов Тихоокеанского ландшафтного пояса. В статье это делается на примере его Сихотэ-Алинской, Сахалинской и Камчатской областей. Рассматриваются результаты изучения структурной организации и районирования. В областях выделены провинции, которые представляются природными моделями «фундаментом» для построения гармонизированных с природой моделей природопользования.

Рассматриваемые в работе орогенные региональные горные и равнинные провинции ландшафтов зоны континентального обрамления и сопряженных с ними окраинных морей это таксоны внутреннего содержания выделенного в единную планетарную ландшафтную структуру Тихоокеанского ландшафтного пояса 
(https://doi.org/10.18411/a-2017-089). Выделены на основе комплексного ландшафтного подхода в понимании зоны перехода континента к океану, основанном на региональном междисциплинарном синтезе, анализе и оценке компонентов его внутреннего содержания (включает фундамент, рельеф, климат, почвы, растительность, биоценозы) $[1,3,4]$ и применения ландшафтной методологии изучения территорий, на основе учета взаимодействия, взаимообусловленности и взаимопроникновения друг в друга компонентов, на основе изучения ландшафтов в условиях окраинноконтинентальной дихотомии, на основе изучения орогенического, орографического, климатического и фиторастительного взаимодействующих между собой факторов. Обособляются внутри ландшафтных областей, включают ландшафты подклассов и родов, определяемые высотностью, типами растительности, рельефом и вещественными комплексами фундамента - четырьмя ведущими факторам: орогеническому, орографическому, климатическому и фиторастительному. Комплексное региональное изучение горных и равнинных провинций ландшафтного пояса как ландшафтных структур континентального обрамления Тихого океана, имеет базовое значение при природопользовании зоны перехода от континента к океану и использовании этого материала для решения вопросов освоения Мирового океана.

Цель публикации - обосновать в Российской науке необходимость на основе применения ландшафтного метода рассматривать орогенные региональные горные и равнинные ландшафтные провинции как индивидуальные важные таксоны континентального обрамления Тихого океана, выделенных как внутреннее содержание Тихоокеанского ландшафтного пояса, как природные структуры диалектической пары геосистемы континент-Мировой океан и обосновать их базовый комплексный характер и как структуры ландшафтной основы-модели освоения зоны перехода и использование материалов при решении определенных регионального уровня вопросов освоения системы континент-Мировой океан. Обособлять внутри ландшафтных областей, с включением ландшафтов подклассов и родов, определяемые высотностью, типами растительности, рельефом и вещественными комплексами фундамента - четырьмя ведущими факторам: орогеническому, орографическому, климатическому и фиторастительному. Ландшафтные провинции рассматривать как важные таксоны природного «фундамента» для построения гармонизированных с континентальной природой и океаном региональных и планетарных научных и практик-моделей освоения (краеведческих, экологических, сельскохозяйственных, экономических, социальных, градостроительных и других).

Материалы и методы. Общая методологическая основа исследования ландшафтный подход, в котором ландшафтному анализу подвергаются геосистемы различных рангов и в конечном итоге дается та или иная географическая оценка ландшафтного пространства объекта исследования, а полученные результаты анализа, синтеза и оценки применяются для решения задач структурной организации и ландшафтного районирования территорий. С методической точки зрения провинции ландшафтных областей, выделяемые в составе Тихоокеанского ландшафтного пояса представляют собой часть единой с Тихим океаном структуры природы и представляются как основа для выполнения задач науки и практик освоения территорий континентального обрамления и окраинных морей Тихого океана и применении их при решении вопросов освоения Мирового океана.

Значимым является то, что в основу рассмотрения орогенных горных и равнинных ландшафтных провинций положены многолетние авторские полевые геолого-географические и географические научные и производственные исследования обширной территории окраинной зоны Востока России, которые в свою очередь включают полевые исследования Сихотэ-Алинской, Сахалинской, Камчатской, Анадырьской ландшафтных областей [5-12]. В целом отметим, что весь полученный полевой и научный материал по ландшафтам анализировался на междисциплинарном 
уровне, осмысливался и формулировался и благодаря этому была определена географическая целостность провинций и не только областей, но и в целом континентального обрамления и сопряженных с ним окраинных морей Тихого океана.

При обосновании применения материалов по горным и равнинным провинциям при освоении окраинно-континентальной переходной зоны к океану использовались материалы практической реализации ландшафтного подхода с применением ландшафтной индикации в различных областях природопользования [2,7]. Особо отметим, что для определения региональной и планетарной ландшафтной целостности горных и равнинных провинций как структурных единиц областей и в целом Тихоокеанского ландшафтного пояса соизмеримых с фокусом максимального взаимодействия океана и Азиатского континента, применены материалы авторских палеогеографических исследований. Применены результаты геологических и палеогеографических реконструкций по установлению генезиса, состава и тектонической эволюции фундамента ландшафтов. Применялась авторская концепция геодинамической эволюции зоны перехода Азиатского континента к океану.

Использовались материалы, полученные по итогам многочисленных экспедиций на Сахалине, Камчатке, Чукотке и других территориям и, в частности, новые векторнослоевые картографические материалы по отдельным регионам зоны континентального обрамления (сихотэ-алинской, сахалинской и др. ландшафтным областям). Использовался материал по выделенным высотно-ландшафтным комплексам горных, островных, озерных геосистем, а также их водосборов.

Весь имеющийся материал анализировался на основе сопряженного анализа и синтеза межкомпонентных и межландшафтных связей с учетом окраинноконтинентальной дихотомии и данных по орогеническому, орографическому, климатическому и фиторастительному факторам формирования географически единых территорий. Получены были следующие результаты.

Результаты. При познании, формулировании структурной организации и районировании ландшафтных областей континентального обрамления Тихого океана как таксонов планетарной Тихоокеанской ландшафтной геосистемы в освоении Мирового океана получен фундаментальный результат настоящих исследований, заключающийся в том, что для реализации рассмотрения структурной организации и районировании ландшафтных областей континентального обрамления Тихого океана в освоении необходимо иметь прежде всего оцифрованную векторно-слоевую морфологическую ландшафтную основу [1]. Такие основы, как в целом по поясу, так и по его отдельным регионам получены (Сихотэ-алинской, Сахалинской ландшафтным областям и др.). Это, прежде всего, оцифрованные векторно-слоевые морфологические ландшафтные модели (векторно-слоевые ландшафтные карты), которые на цифровом уровне дают знание строения географического пространства рассматриваемого объекта. Этот результат позволяет проанализировать территории по оцифрованным выделам ландшафтов. Сравнить внутреннее содержание не только рассматриваемых в работе таких таксонов как горных и равнинных провинций, но и таких таксонов как вид, род, подкласс, класс, тип, округ ландшафтов. Затем решать задачи по структурной организации и ландшафтному районированию. Тем более, что результат включает современное компьютерное программное обеспечение.

Синтез, анализ обеспеченности орогенных горных и равнинных провинций континентального обрамления Тихого океана современными векторно-слоевыми картографическими материалами, составленными на основе современных требований картографии и математического обеспечения показывает следующую общую картину такой обеспеченности. Составлены карты и объяснительные записки к ним:

1. Карта ландшафтов Тихоокеанского ландшафтного пояса, областей и прилегающих морей в масштабе 1: 3000000 (автор Старожилов В.Т.). На карте также выделены ландшафтные области: Сихотэ-алинская, Нижнеамурская, Приохотская, 
Колымская, Анадырьская, Чукотская, Корякская, Камчатско-Курильская, Сахалинская. Представлены сопряженные с областями окраинные моря исследования.

2. Ландшафтная карта Приморского края масштаба 1:1 000000 (автор Старожилов В.Т., сжатая версия электронной карты ландшафтов Приморского края масштаба 1:500 000);

3. Карта ландшафтного районирования Приморского края масштаба 1:1 000 000 (автор Старожилов В.Т.). Выделено 54 округа, 8 провинций, 4 области;

4. На основе базовой карты ландшафтов Приморского края (на карте картографировано 3156 выделов ландшафтов), так как она цифровая, то было получено отдельных 3156 карт по всем выделенным на карте выделам ландшафтов. На основе карты районирования, так как она цифровая векторно-слоевая, то было получено отдельных 66 карт ландшафтных единиц районирования;

5. Впервые для АТР издана (автор Старожилов В.Т.) объяснительная записка к карте ландшафтов Приморского края масштаба 1: 500 000. В ней описано 3156 выделов ландшафтов;

6. На основе основной векторно-слоевой карты ландшафтов Приморского края составлены частные векторно-слоевые карты ландшафтов и высотноландшафтных комплексов островных, озерных и горных водосборов Тихоокеанского ландшафтного пояса, в том числе составлена карта ландшафтов и высотноландшафтных комплексов водосбора озера Ханка;

7. Ландшафтная карта острова Сахалин в масштабе $1: 500$ 000. В настоящее время карта и объяснительная записка к ней готовятся к изданию;

8. Ландшафтная карта урочищ и групп урочищ о. Русский и прилегающих к нему островов Владивостокского городского округа масштаба 1: 25 000;

9. Карта положения и эволюции палеоструктур и сопряженных с ними элементов зоны перехода северо-востока Азии к Тихоокеанской плите.

Карты представляются значимым академическим творением в сфере цифровых карт, основанном на огромном опыте изысканий в области теории, а также практике ландшафтоведения, и вплоть до этих пор в части обзорности и содержательности не имеет аналогов для территории Азиатско - Тихоокеанского региона (АТР), охватывая Азиатские государства. Карты принадлежат к картам новейшего поколения, в которых в перспективе станут отображать в цифровом виде не отраслевые слои компонентов, но слои классификационных единиц ландшафтов. Немаловажно в таком случае то, что карты нацелены на практическую реализацию ландшафтного подхода в освоении земель, а также способны быть применены как естественные модели «фундамент» с целью формирования гармонизованных с природой экологических, гидрологических, экономических, социальных и др. моделей освоения территорий.

Важно отметить, что вышеотмеченные карты в масштабе 1: 500 000, 1; 1000 000, 1: 3000000 и др. континентального обрамления Тихого океана по Тихоокеанскому ландшафтному поясу и отдельно по его областям (сихотэалинской, сахалинской, камчатской и др.) составлены в разработанной Дальневосточной ландшафтной школой профессора В.Т. Старожилова системе ландшафт, вид, род, класс, тип, округ, провинция, область, пояс.

В целом по результатам синтеза, анализа и оценки всех имеющихся материалов и в том числе полевых исследований автора (30 полевых сезонов) сихотэалинской, сахалинской, камчатской, анадырьской ландшафтных областей установлены ландшафтные особенности орогенных горных, межгорных равнинных территорий континентального обрамления Тихого океана. Весь полученный статистический научный и полевой материал систематизирован, определены и картографированы границы таксонов, установлен и формулировался статус ландшафтного положения и внутреннего содержания провинций в иерархическом ряду ландшафтов Тихоокеанского ландшафтного пояса. Установлены также статус положения и 
формулировалось значение и роль таксона при проведении ландшафтного районирования пояса. Ниже, как пример, приводится описание особенностей и статус горных и межгорных равнинных провинций Сихотэ-Алинской (рис. 1), Сахалинской и Камчатской ландшафтных областей Тихоокеанского ландшафтного пояса.

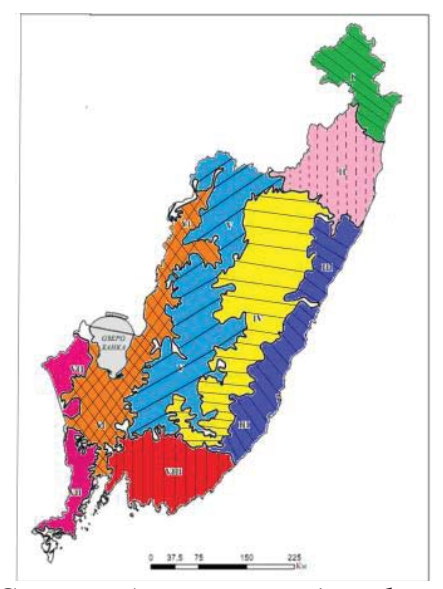

Рис. 1. Ландшафтные провиничи Сихотэ-Алинской ландшафтной области: I-Самаргинская, IIСеверо-Сихотэ-Алинская, III - Восточно-Сихотэ-Алинская, IV-Центрально-Сихотэ-Алинская, VЗападно-Сихотэ-Алинская, VI - Западно-Приморская равнина, VII - Восточно-Маньчжурская, VIIIЮжно-Приморская

В Сихотэ-Алинской ландиафтной области Тихоокеанского ландшафтного пояса выделяются Самаргинская, Северо-Сихотэ-Алинская, Восточно-СихотэАлинская, Центрально-Сихотэ-Алинская, Западно-Сихотэ-Алинская, ЗападноПриморская равнина, Восточно-Маньчжурская, Южно-Приморская провинции.

Самаргинская провинция, охватывающая бассейны рек Самарга, Единка, Венюковка и в их верховьях отроги осевого хр. Сихотэ-Алинь, включает горную территорию дальневосточного горного класса ландшафтов с характерным для нее сочетанием ландшафтов горно - смешанно-широколиственного доминантного и горнотемнохвойного подклассов, массивно-и расчлененносреднегорных полисубстратных, низкогорных терригенного и вулканогенно-терригенного родов. Характеризуется сменой поясов: смешанно-широколиственный сменяется темнохвойным, затем редким тундровым. Фундамент сложен доминантным алевролит-песчаниковым вещественным комплексом. Он прорывается позднемезозойскими интрузиями преимущественно кислого состава. На значительных площадях вещественный комплекс перекрыт меловыми вулканитами Восточно-Сихотэ-Алинского вулканического пояса и неогеновыми базальтоидами зон рифтогенной активизации Сихотэ-Алиня. Фундамент на 99,5\% закрыт чехлом рыхлых образований и залегает на глубине от 0 м (скальные выходы) до 5 - 10 м.

Северо-Сихотэ-Алинская провинция, охватывает территорию верхнего течения p. Бикин со всеми его притоками, до западной границы Верхне-Бикинской депрессии и бассейна рек восточного макросклона Сихотэ-Алиня (Кабанья, Светлая, Кузнецовка, Максимовка) (рис.1). Включает горную территорию дальневосточного горного класса ландшафтов с характерным для нее сочетанием ландшафтов горно - смешанношироколиственного доминантного и характерного горно-темнохвойного подклассов, массивно-и расчлененносреднегорных полисубстратных, низкогорных терригенного и вулканогенно-терригенного родов. В пределах Верхне-Бикинской депрессии включает ландшафты равнинного эрозионно-аккумулятивного и долинно-речного рода. Характеризуется сменой поясов: смешанно-широколиственный сменяется темнохвойным, затем редким тундровым. Фундамент сложен преобладающими породами алевролит-песчаникового вещественного комплекса. Пятую часть занимают базальты плато (Единское, Зевинское, Максимовское) зон палеоген-неогеновой 
рифтогенной активизации. Породы алевролит-песчаникового комплекса прорываются многочисленными, сравнительно мелкими интрузиями кислого, реже среднего, состава. Фундамент закрыт чехлом рыхлых полигенетических отложений и залегает на глубине от 0 м (скальные выходы) до 5 - 10, редко 20 м.

Западно-Сихотэ-Алинская провинция охватывает верхнее течение р. Уссури, бассейны рек Арсеньевка, Крыловка, Быстрая, Маревка и среднее течение рек Малиновка, Ореховка, Большая Уссурка, Бикин. Включает горную территорию дальневосточного горного класса ландшафтов с характерными для нее ландшафтами горно- смешанно-широколиственного доминантного подкласса, доминантного низкогорного терригенного и вулканогенно-терригенного родов. Характеризуется растительностью смешанно-широколиственного пояса. Фундамент по составу и структурно-тектоническому положению сложный. Восточная часть сложена интенсивно тектонизированными алевролитово-кремнисто-вулканогенным, кремнистоглинистым, вулканогенно-кремнисто-алевролитовым, сланцевым вещественными комплексами Краевого Сихотэ-Алинского шва, эффузивными породами кислого и основного состава. Западная часть провинции сложена алевролит-песчаниковым вещественным комплексом, эффузивами кислого состава. Вещественные комплексы прорваны разновозрастными интрузиями кислого состава. Фундамент закрыт чехлом рыхлых полигенетических накоплений и залегает на глубине 2-20 м.

Центрально-Сихотэ-Алинская провинция охватывает наиболее возвышенную часть горного Сихотэ-Алиня от хр. Боголадза на севере до хр. Пржевальского на юге включительно. Включает горную территорию дальневосточного горного класса ландшафтов с характерным для нее сочетанием ландшафтов горно- смешанношироколиственного и горно-темнохвойного подклассов, доминантными массивно-и расчлененносреднегорных полисубстратных, низкогорных терригенного и вулканогенно-терригенного родов. Характеризуется сменой поясов: смешанношироколиственный сменяется темнохвойным, затем редким тундровым. Фундамент сложен доминантными алевролит-песчаниковым, песчаниково-алевролитовым вещественными комплексами, эффузивами кислого, реже среднего, состава. Породы осадочных комплексов прорваны многочисленными интрузиями кислого состава. Фундамент закрыт чехлом рыхлых отложений и залегает на глубине до 10 м.

Особо отметим, что рассматриваемая провинция это зона главного водораздела Сихотэ-Алиня, где распространяется циркуляция переувлажненных холодных воздушных масс, поступающих с Охотского и Японского морей в весеннийраннелетний период, и относительно теплых масс - в осенне-зимний. Формируется барьерный тип микроклимата, отличающий провинцию от других.

Восточно-Сихотэ-Алинская провинция расположена на востоке СихотэАлинской области и ограниченной береговой линией Японского моря, а на западе граница проходит вблизи водораздела Сихотэ-Алиня. Включает горную территорию дальневосточного горного класса ландшафтов с характерным для нее сочетанием ландшафтов горно - смешанно-широколиственного и горно-темнохвойного подклассов, массивно-и расчлененносреднегорных полисубстратных, низкогорных терригенного и вулканогенно-терригенного родов. Характеризуется сменой поясов: смешанно-широколиственный сменяется темнохвойным, затем редким тундровым. Фундамент представлен верхнемеловыми и палеогеновыми эффузивами ВосточноСихотэ-Алинского вулканического пояса, прорванными интрузиями различного состава. Среди вулканитов наблюдаются редкие «окна», сложенные кремнистокарбонатно-песчаниково-алевролитовым вещественным комплексом. Фундамент закрыт чехлом рыхлых отложений и залегает на глубине до 5, 10 редко до 20 м.

Восточно-Маньчжурская ландшафтная горная провинщия включает ВосточноМаньчжурскую складчатую горную территорию дальневосточного горного класса ландшафтов с характерными для нее горно-лесным смешанно-широколиственным 
классом, низкогорным вулканогенно-терригенным родом и видами ландшафтов с широколиственными группировками растительности на бурых лесных и других почвах, развивающимися в условиях западного грабен-горстового борта Амуро-Уссурийской рифтогенной структуры. По внутреннему содержанию делится на три морфологически самостоятельные части: к северу от долины р. Раздольная располагается Пограничный горный район, к югу - Борисовское базальтовое плато и Хасанско-Барабашский горный район.

Пограничный горный район представляет собой систему небольших по протяженности водораздельных горных хребтов высотой 600 - 800 м (наивысшая отметка - г. Кедровая, 964 м). Все линии водоразделов по направлению к оз. Ханка понижаются, переходя в низкогорье и холмисто-увалистую равнину. Вертикальная расчлененность местности 200 - 500 м, горизонтальная - до 1 км на 1 кв. км.

Хасанско-Барабашский горный район, расположенный в юго-западной части края, состоит из хр. Черные Горы общего северо-восточного направления и нескольких коротких поперечных водоразделов юго-восточного и южного направления. Долины всех наиболее крупных водотоков этой части края открыты южным и юго-восточным влагонесущим потокам морского воздуха, что накладывает своеобразный отпечаток на климат, почвы и растительность. По абсолютным отметкам (до 900 - 1000 м) это типичное низкогорье, но с высокой степенью вертикального $(300-600$ м) и горизонтального расчленения (до 1,5 км на 1 кв. км площади). Реки описываемого района типичные горные.

Уссури-Ханкайская равнинная ландшафтная провинция занимает пространство между Западно-Сихотэ-алинской и Восточно-Маньчжурской горными провинциями. Включает оз. Ханка и Уссури-Ханкайскую равнину с бассейнами рек Мельгуновка, Комиссаровка, Илистая, Белая, среднее течение р. Уссури, нижнее течение р. Большая Уссурка и др. Включает равнинную территорию дальневосточного равнинного класса ландшафтов с характерным для нее сочетанием ландшафтов лесостепного равнинного и долинно-речного подкласса и равнинного эрозионно-аккумулятивного и долинноречного и приморско-равнинного родов, различных лесных видов с широколиственномелколиственно-смешанными, долинными широколиственными с липами, кленом и дубом, редколесно-порослево-дубовых, мелколиственных вейниково-осоковых, луговых осоко-вейниковых на лугово-бурых, бурых лесных, задернованных дерновоторфянисто-глеевых, луговых пойменных и болотных почвах. Доминантными являются местности с четвертичными аллювиально-озерными (мощность от 1,0 до 60 м) и гранитоидными, сланцевым, карбонатно-гнейсовым и другими комплексами фундамента.

Фундамент сложен палеозойскими сланцевым, гнейсово-сланцевым, сланцевокарбонатным, кремнисто-карбонатным, алевролито-песчаниковым и гранитоидным вещественными комплексами. Фундамент перекрыт мощным чехлом четвертичных озерно-аллювиальных отложений и залегает на глубине до 110 м в районе оз. Ханка. В направлении от озера к внешним границам провинции глубина залегания уменьшается до 15 - 20 м.

Южно-Приморская провинция расположенна в южной части Сихотэ-Алинской области, в басс. рек Шкотовка, Киевка, Партизанская и др. Включает горную территорию дальневосточного горного класса ландшафтов с характерным для нее сочетанием ландшафтов горно - смешанно-широколиственного и горно-темнохвойного подклассов, массивно-и расчлененносреднегорных полисубстратных, низкогорных терригенного и вулканогенно-терригенного родов. Характеризуется сменой поясов: доминантный смешанно-широколиственный сменяется темнохвойным. Фундамент сложен метаморфическим, метагабброидным комплексами, прорванными гранитами зон активизации. На западе провинции развиты континентальные осадочные породы чехла и зон активизации Ханкайского массива алевролит-песчаникового, песчаниково- 
алевролитового, песчаниково-конгломератового вещественных комплексов. На востоке развиты алевролит-песчаниковый, вулканогенно-кремнисто-алевролитовый, эффузивный кислого и среднего состава вещественные комплексы. Они прорваны интрузиями гранитов и гранодиоритов. Фундамент перекрыт чехлом рыхлых отложений и залегает на глубине от 2 до 20 м.

В Сахалинской ландшафтной области Тихоокеанского ландшафтного пояса выделяются_ ландшафтные горные и равнинные провинции: горные ВосточноСахалинская и Западно-Сахалинская, равнинные Центрально-Сахалинская и СевероСахалинская (Рис.2).

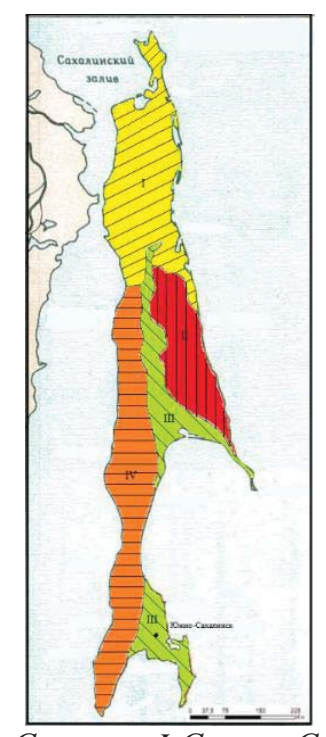

Рис.2. Ландшафтные провинции острова Сахалин: I-Северо-Сахалинская; II-Восточно-Сахалинская; IIIЦентрально-Сахалинская; IV-Западно-Сахалинская.

Восточно-Сахалинская ландшафтная горная провинция включает ВосточноСахалинскую складчатую горную территорию дальневосточного горного класса ландшафтов и гольцовые и подгольцовые полисубстратные, среднегорные, низкогорные и горно-долинные полисубстратные, терригенные и вулканогеннотерригенные роды и горно-темнохвойные и другие подклассы и виды ландшафтных геосистем. Это среднегорная, с крутыми склонами и острыми вершинами территория. Фундамент сложен алевролит-песчаниковым с телами кислого, основного и ультраосновного состава вещественным комплексом

Западно-Сахалинская ландшафтная горная провинция включает ЗападноСахалинскую складчатую горную территорию дальневосточного горного класса ландшафтов с доминантным темнохвойным подклассом, низкогорным терригенным родом и видами ландшафтов с доминантными темнохвойными группировками растительности на бурых лесных и других почвах. Это среднегорная, с крутыми склонами и острыми вершинами территория. Фундамент сложен алевролитпесчаниковым с телами кислого состава вещественным комплексом.

Центрально-Сахалинская ландшафтная равнинная провинция включает Центрально-Сахалинскую равнину (располагается между Восточно-Сахалинскими и Западно-Сахалинскими горами), темнохвойные равнинные и долинно-речные ландшафтные геосистемы Томь-Поронайской низменности с темнохвойными лесами на буро-таежных почвах, с лугами, болотами, марями с болотно-торфяными и пойменными лугово-дернованными почвами. Представлена эрозионно-аккумулятивным и озерным равнинным и долинно-речным родами ландшафтов.

Северо-Сахалинская ландшафтная равнинная провинция занимает СевероСахалинская равнину и включает районы западного побережья, центральную часть и 
восточного побережья. Ландшафты западного побережья включают полосу низких морских террас сложенных песками, Это слабо всхломленная, с дюнами, заболоченная на пониженных местах равнина с лиственичным редколесьем и кедровым стлаником. Ландшафты центральной части занимают большую часть области, представляет собой приподнятую, всхолмленную равнину с болотами, гарями, редколесьем лиственницы и зарослями кедрового стланика. Ландшафты восточного побережья включают узкую полосу песчаных морских террас, кос и пересыпей с обширными лагунами с редкими редколесьями лиственницы и кедрового стланика.

В Камчатско-Курильской ландшафтной области Тихоокеанского ландшафтного пояса выделяются ландшафтные горные и равнинные провинции: равнинная Западно-Камчатская, горная Срединно-Камчатская, равнинная ЦентральноКамчатская, горная Восточно-Камчатская (Рис.3).

Западно-Камчатская ландшафтная равнинная провинция занимает ЗападноКамчатскую равнину и включает районы западного побережья. Представлена равнинным классом ландшафтов с характерным для нее сочетанием тундровых ландшафтов равнинного и долинно-речного подкласса и равнинного эрозионноаккумулятивного и долинно-речного и приморско-равнинного родов, различных заболоченных травянисто - лесных видов с зарослями водянки и голубики и клюквой, увалистых каменноберезовых травянистых лесных и редколесных, в предгорьях с обогащением злаково-папортниковым высокотравием, долинных тополево-чозениевых лесов чередующихся с разнотравными лугами с преобладающими перегнойными почвами.

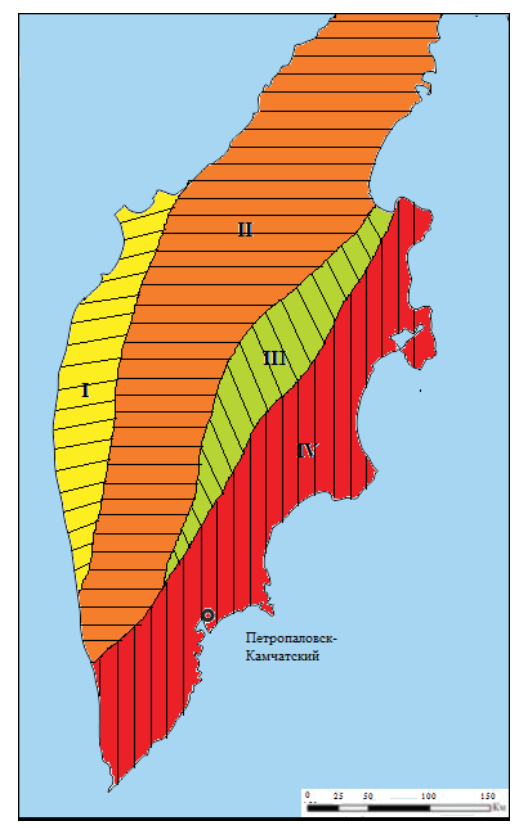

Рис.3 Ландшафтные провиниии полуострова Камчатка: I-Западно-Камчатская; II-СрединноКамчатская; ІІІ-Центрально-Камчатская; IV-Восточно-Камчатская.

Срединно-Камчатская ландшафтная горная провинщия занимает СрединоКамчатский горный район и включает горную территорию Срединного Камчатского хребта. Представлена горным классом ландшафтов, гольцовым, высокогорным вулканогенным, среднегорным полисубстратным и низкогорным полисубстратным родами и видами ландшафтов с елово-лиственичными группировками растительности на различных почвах, с каменноберезовыми лесами, виды с зарослями кедрового стланика и кустарниковой ольхи, виды горных тундр и альпийских лугов с кустарничками рододендрона, а также долинно-речные с тополями, чозении, зарослями 
кустарниковой ивы. Преобладающие высоты вершинного уровня 1500-2000м, Наиболее высокая - Ичинская Сопка - высотой 3607 м.

Центрально-Камчатская ландшафтная равнинная провинция занимает Центрально-Камчатский равнинный район и включает равнинную территорию с юга от верховьев р. Быстрой до берегов Карагинского залива, охватывая сопряженные равнинные и котловинные структуры, крупнейшая из которых занимает долину р. Камчатка. Представлена равнинным классом ландшафтов с характерным для нее сочетанием тундровых ландшафтов равнинного и долинно-речного подкласса и равнинного эрозионно-аккумулятивного и долинно-речного родов, различных заболоченных травянисто - лесных видов с редколесно-кустарниковыми зарослями, видов редколесий из каменной березы и кустарниковой ольхи, на возвышенных участках видов с зарослями кедрового стланика, вида с хвойными лесами из лиственницы курильской и ели аянской с участием каменной березы и кедрового стланика. На водоразделе р. Камчатка и Быстрая и в истоках р. Камчатка развиты виды ландшафтов с травянистыми лесами из каменной березы и лесолуговые с участием белой березы.

Восточно-Камчатская ландшафтная горная провинция занимает ВосточноКамчатский горный район и включает горную территорию Восточных хребтов и Восточно-Камчатской высокогорной ледниково-вулканической системы. Здесь расположены вулканические группы: Карымская, Семячинская, Жупановская, Кроноцкая, Корякская. Представлена горным классом ландшафтов; горнотундровым, лесолуговым, горно-лесным подклассом; гольцовым, высокогорным вулканогенным, среднегорным полисубстратным и низкогорным полисубстратным родами и видами ландшафтов с парковыми высокотравными лесами из березы Эртмана, видом с кустарниковыми зарослями из кедрового стланика и кустарниковой ольхи; видом с лесами из лиственницы камчатской с богульником и кедровым стлаником; видом с лесами из каменной и белой берез; эрозионно-долинными видами кустарниковоразнотравными белоберезовиками с ольхой пушистой; видом с лесами из чозении, тополя Комарова и черемухи азиатской с подлеском с шиповником, жимолостью съедобной, рябиной бузинолиственной. С высоты 800-1000м начинают преобладать виды ландшафтов с зарослями кедрового стланика и кустарниковой ольхи. Верхние части склонов представлены видами с горнотундровыми группировками и альпийскими лугами, а на каменистых склонах формируются лишайниковые тундры.

Заканчивая характеристику примеров горных и равнинных провинций ландшафтов важно отметить, что, как показали исследования Тихоокеанского ландшафтного центра ДВФУ в освоении геосистемы континент-Мировой океан, установление статистических данных по таксонам ландшафтов морфологическому строению территорий- это только первый этап ландшафтного изучения Востока России и Тихоокеанского ландшафтного пояса. Специальное изучение ландшафтной школой профессора В.Т. Старожилова фундаментальных направлений изучения ландшафтов и их картографирования установлено то, что кроме морфологического направления выделяются: индикационное, ландшафтных узловых структур освоения, планирования и проектирования. Отмечается, что все они сопровождаются составлением векторно-слоевых разномасштабных индикационных, узловых структур освоения, планирования и проектирования векторно-слоевых ландшафтных карт (doi: 10.18411/1j-09-2020-35). Поэтому для получения полной характеристики объектов освоения фундаментальные исследования территорий должны быть продолжены в отмеченных выше направлениях. Такие работы уже проводятся в Тихоокеанском международном ландшафтном центре ШЕН ДВФУ под руководством профессора В.Т. Старожилова.

Также установлено, что применение материалов по горным и равнинным провинциям в освоении геосистемы континент-Мировой океан направлено 
на рациональное освоение и использование территорий, минимизацию глобальных и региональных последствий изменения природы и общества, поиск и внедрение инновационных подходов в устойчивом, экологически сбалансированном и безопасном развитии обширного региона. Основывается на анализе, синтезе и оценке не только теоретических результатов научных исследований, но и практической реализации ландшафтного подхода в различных отраслях производства Тихоокеанского ландшафтного пояса России.

Заключение. Констатируется, что на основе научных и полевых исследований Тихоокеанского международного ландшафтного центра ДВФУ и Ландшафтной школы профессора Старожилова получен прежде всего фундаментальный статистический и картографический ландшафтный материал по горному и равнинному ландшафтному обрамлению Тихого океана. На его основе формулируется и картографируется в ландшафтных границах географически целостные горные и равнинные провинции ландшафтов как таксоны иерархической системы ландшафтов геосистемы континентМировой океан (провинции выделяется в системе ландшафтов: ландшафт, вид, род, подкласс, класс, тип, округ, провинция, область, пояс). Установлены особенности таксона в Тихоокеанском ландшафтном поясе России по иерархическим единицам его районирования - по округам, областям. Обособляются внутри ландшафтных областей, включают ландшафты подклассов и родов, определяемые высотностью, типами растительности, рельефом и вещественными комплексами фундамента - четырьмя ведущими факторам: орогеническому, орографическому, климатическому и фиторастительному.

На основе полученных и формулируемых итогов синтеза и анализа данных установлено и утверждается, что в Российской науке необходимо на основе применения ландшафтного метода рассматривать орогенные региональные горные и равнинные провинции как индивидуальные важные таксоны континентального обрамления Тихого океана, выделенных как внутреннее содержание Тихоокеанского ландшафтного пояса, как природные таксоны структур и организации диалектической пары геосистемы континент-Мировой океан и применять их базовый комплексный характер как таксоны структуры ландшафтной основы-модели освоения зоны перехода и использовать эти материалы при решении разномасштабного уровня вопросов освоения системы континент-Мировой океан.

Ландшафтные горные и равнинные провинции рассматривать как единицы природного «фундамента» для построения гармонизированных с континентальной природой и океаном региональных и планетарных научных и практик-моделей освоения (краеведческих, экологических, сельскохозяйственных, экономических, социальных, градостроительных и других).

1. Старожилов В.Т. Природопользование: практическая ландшафтная география. / учебник. Школа естественных наук ДВФУ, Тихоокеанского международного ландшафтного центра, Школа естественных наук ДВФУ. Владивосток, 2018. 276с

2. Старожилов В.Т. Эколого-ландшафтный подход в формировании региональной экологической политики на территории стран АТЭС / В сборнике: Шестые Гродековские чтения. Актуальные проблемы исследования Российской цивилизации на Дальнем Востоке. межрегиональная научнопрактическая конференция. Правительство Хабаровского края. Хабаровск, 2009. С. 24-28.

3. Старожилов В.Т. Региональные компоненты и факторы структуры и пространственной организации ландшафтов юга Дальнего Востока (на примере Приморского края). - Владивосток, 2007.

4. Старожилов В.Т. Ландшафтное картографирование территорий Приморского края // Известия Российской академии наук. Серия географическая. -2010. -№ 2. -С. 82-89.

5. Старожилов В.Т., Зонов Ю.Б. Ландшафтные предпосылки устойчивого развития территорий. / В сборнике: Природа без границ. Материалы I Международного экономического форума. Администрация Приморского края. 2006. С. 261-265. 
6. Старожилов В.Т. Ландшафтное районирование Приморского края. Вестник Дальневосточного отделения Российской академии наук. 2010. № 3 (151). С. 107-112.

7. Старожилов В.Т., Леоненко А.В., Крупская Л.Т., Дербенцева А.М. Геоэкология минеральносырьевого природопользования ландшафтов юга Дальнего Востока./ Министерство образования и науки Российской Федерации, Федеральное агентство по образованию, Дальневосточное отделение Российской академии наук, Институт горного дела, Дальневосточный федеральный университет. Владивосток, 2009.

8. Старожилов В. Т. Геодинамическая эволюция зон перехода северо-востока Азии к Тихоокеанской плите / В. Т. Старожилов // Гидрометеорологические и географические исследования на Дальнем Востоке: материалы 5-й юбилейной научн. конф. «К всемирным дням воды и метеорологии». Владивосток, 2004. - С.85-88.

9. Старожилов В.Т. Ландшафтные геосистемы Сахалинского звена окраинно-континентального ландшафтного пояса Тихоокеанской России // Проблемы региональной экологии. - 2016. - № 5. C. 53-57.

10. Старожилов В.Т. Эколого-ландшафтный подход к промышленным территориям юга Дальнего Востока // В сборнике: Современные геофизические и географические исследования на Дальнем Востоке России. материалы 9-й научной конференции, Владивосток: конференция приурочена к Всемирным дням воды и метеорологии, а также к 110-летию ДВГУ и 45-летию ГФФ. Дальневосточный государственный университет, Институт окружающей среды ; под редакцией Н. В. Шестакова. Владивосток, 2010. С. 155-158.

11. Старожилов В.Т. Проблемы ресурсопользования, структура и пространственная организация ландшафтов приокеанских Дальневосточных территорий // В сборнике: Науки о Земле и отечественное образование: история и современность. материалы Всероссийской научнопрактической конференции, посвященной памяти академика РАО А. В. Даринского. Российский государственный педагогический университет им. А. И. Герцена, факультет географии. 2007. С. 310-312.

12. Старожилов В. Т. Ландшафтные геосистемы Сахалинского звена Тихоокеанской России // В сборнике: Научная дискуссия: гуманитарные, естественные науки и технический прогресс. Материалы VII Всероссийской научно-практической конференции. 2015. С. 54-64.

\section{Теймурзаде Л.Т.к. \\ Живетский ярус среднего девона (средне и верхнеживетский подъярусы) Нахичеванской АР и его зональное расчленение}

Азербайджанский Государственный Университет Нефти и Промышленности (Азербайджан, Баку)

doi: 10.18411/lj-04-2021-75

\section{Аннотация}

Отложения живетского яруса широко развиты в западной части Нахичеванской Автономной Республики, они представлены в основном карбонатными породами мощными слоями известняков, часто органогенного происхождения; в верхней части довольно в большом количестве участвуют и терригенные материалы: аргиллиты, песчаники, алевролиты и кварциты. В составе живетского яруса Нахичеванской АР установлены две свиты: садаракская и арпачайская.

Садаракская свита охватывает в своем стратиграфическом объеме две брахиоподовые зоны: 1) зона Stringocephalus burtini и 2) зона Crurithyris inflatus.

В составе арпачайской свиты выделяются две брахиоподовые зоны: 1) зона Spinocyrtia subcuspidata и 2) зона Undispirifer undiferus - Emanuella pseudovolhynica.

Каждая из этих зон характеризуется своеобразным, стабильным, присущим только ей, фаунистическим комплексом, но в то же время они отличаются друг от друга различным литологическим составом.

Ключевые слова: разрез, отложения, свита, зона, ярус, фауна, горизонт, биостратиграфические зоны, подсвита. 